\title{
Estradiol increases angiotensin II type 1 receptor in hearts of ovariectomized rats
}

\author{
Vincent Ricchiuti, Christine G Lian, Eveline M Oestreicher, Loc Tran, James R Stone ${ }^{1}$, Tham Yao, \\ Ellen W Seely, Gordon H Williams and Gail K Adler
}

Division of Endocrinology, Diabetes and Hypertension, Department of Medicine, Harvard Medical School, Brigham and Women's Hospital, 221 Longwood Avenue, Boston, Massachusetts 02115, USA

${ }^{1}$ Department of Pathology, Massachusetts General Hospital, Harvard Medical School, Boston, Massachusetts, USA

(Correspondence should be addressed to V Ricchiuti; Email: vricchiuti@partners.org)

\begin{abstract}
We tested the hypothesis that $17 \beta$-estradiol $\left(\mathrm{E}_{2}\right)$ has dual effects on the heart, increasing levels of proteins thought to have beneficial cardiovascular effects (e.g. endothelial nitric oxide (NO) synthase (eNOS)) as well as those thought to have detrimental cardiovascular effects (e.g. type 1 angiotensin II (Ang II) receptor $\left(\mathrm{AT}_{1} \mathrm{R}\right)$ ). Ovariectomized Wistar rats consuming a high-sodium diet received one of four treatments ( $n=7$ per group): group 1, placebo pellets; group 2, $\mathrm{E}_{2}$ $\left(0.5 \mathrm{mg} /\right.$ pellet, 21-day release); group 3, NOS inhibitor, $N^{\omega}{ }_{-}$ nitro-L-arginine-methyl-ester (L-NAME; $40 \mathrm{mg} / \mathrm{kg}$ per day for 14 days) plus Ang II (0.225 mg/kg per day on days 11-14); group $4, E_{2}$ plus L-NAME/Ang II. $E_{2}$ increased cardiac levels of estrogen receptors ESR1 and ESR2, an ESR-associated membrane protein caveolin-3, eNOS, and phosphorylated (p)eNOS, thus, exerting potentially beneficial cardiovascular
\end{abstract}

effects on NO. However, $E_{2}$ also increased cardiac levels of proteins associated with cardiovascular injury and inflammation including, $\mathrm{AT}_{1} \mathrm{R}$, protein kinase $\mathrm{C}$ delta (PRKCD), phosphorylated PRKC, and phosphorylated extracellular signal regulated kinase (pMAPK) 3/1, plasminogen activator inhibitor1 (PAI-1), osteopontin and ED-1, a monocyte/macrophagespecific protein. $\mathrm{E}_{2}$ treatment led to similar protein changes in the hearts of L-NAME/Ang II-treated rats except that the increase in peNOS was prevented, and L-NAME/Ang II and $\mathrm{E}_{2}$ had additive effects in increasing cardiac PRKCD and PAI-1. Thus, the highest levels of cardiac PAI-1 and PR KCD occurred in L-NAME/Ang II-treated rats receiving $\mathrm{E}_{2}$. In summary, $\mathrm{E}_{2}$ treatment increased cardiac expression of $\mathrm{AT}_{1} \mathrm{R}$ as well as the expression of pro-inflammatory and prothrombotic factors.

Journal of Endocrinology (2009) 200, 75-84

\section{Background}

The incidence of cardiovascular disease among women is low before menopause and steadily increases after the onset of menopause (Mendelsohn \& Karas 1999). This increase is believed to result in part from the loss of endogenous estrogen and its associated cardioprotective effects (Stampfer et al. 1991). In observational human studies, estrogen replacement therapy in postmenopausal women is associated with a reduced risk of cardiovascular disease (Pinto et al. 1997). However, the Women's Health Initiative (WHI) study (Rossouw et al. 2002) and the Heart and Estrogen/Progestin Replacement Study (Hulley et al. 1998) do not support the concept that hormone replacement therapy protects the cardiovascular system and, in fact, suggest the opposite view that such therapy may increase the risk of cardiovascular disease. Further analysis of the WHI data suggests that estrogen plus progesterone therapy was beneficial in healthy, young postmenopausal women, but increased cardiovascular risk when treatment was initiated in older postmenopausal women with established coronary artery disease (Herrington et al. 2000, Manson et al. 2003). The reasons for the disparate results regarding the cardiovascular effects of estrogen are controversial in part due to an incomplete understanding of the mechanism underlying estrogen's effects on the cardiovascular system.

Many experimental studies in animals and isolated cells support the belief that estrogen protects the cardiovascular system (Huang et al. 2000) via activation of estrogen receptors (ESR)-1 and 2 (Mendelsohn \& Karas 1999). Animal studies show beneficial effects of $17 \beta$-estradiol $\left(\mathrm{E}_{2}\right)$ on atherosclerosis (Hayashi et al. 1992), inflammation (Koh 2002), and endothelial or vascular function (Gorodeski et al. 1995, Crews \& Khalil 1999). Studies also demonstrate that estrogen modulation of endothelial nitric oxide (NO) synthase (eNOS) may be a mechanism of cardiac protection (Brunner et al. 2003, Khalil 2005).

Other studies suggest that estrogen activates the reninangiotensin (Ang)-aldosterone system (RAAS), which could be a mechanism of cardiac injury. In humans, estrogen increases circulating levels of Ang II (Schunkert et al. 1997) and intrarenal Ang II activity (Seely et al. 2004), which is associated with a 
decrease in renal blood flow. In animal models of cardiovascular injury due to an activated RAAS, estrogen increases stroke and renal injury (Stier et al. 2003, Oestreicher et al. 2006). This increase in renal injury is associated with an increase in renal cortical levels of Ang II type 1 receptor $\left(\mathrm{AT}_{1} \mathrm{R}\right)$ protein and mRNA (Oestreicher et al. 2006).

As estrogen stimulates expression of some proteins that might have beneficial cardiovascular effects as well as others that might have detrimental effects, the goal of this study was to determine the balance of $\mathrm{E}_{2}$ effects on cardiac proteins involved in the early steps of cardiac injury. We examined the effects of $\mathrm{E}_{2}$ replacement in ovariectomized (OVX) rats on cardiac levels of eNOS, $\mathrm{AT}_{1} \mathrm{R}$, and $\mathrm{AT}_{1} \mathrm{R}$ signaling pathways, and inflammatory and prothrombotic proteins. Furthermore, we tested the hypothesis that the adverse cardiac effects of $E_{2}$ would predominate in a rodent model of cardiovascular injury induced by high Ang II and impaired NO production (Rocha et al. 2000, Martinez et al. 2002, Oestreicher et al. 2003). In this rat model, treatment with Ang II and the NOS inhibitor $N^{\omega}$-nitro-L-arginine-methyl-ester (L-NAME) causes cardiac inflammation and increases the prothrombotic factor plasminogen activator inhibitor (PAI-1; Oestreicher et al. 2003).

\section{Materials and Methods}

\section{Experimental animals}

Experiments used 10-week-old female Wistar rats (Charles River Lab, Wilmington, MA, USA) that underwent bilateral ovariectomies (OVX). Rats had ad libitum access to drinking fluid. They were housed in individual metabolic cages in a climate-controlled environment $\left(22 \pm 1^{\circ} \mathrm{C}\right)$ with a $12 \mathrm{~h}$ light: $12 \mathrm{~h}$ darkness cycle. All rats received $1 \% \mathrm{NaCl}$ to drink. Rats were killed at the end of the 14-day treatments without respect to timing of the 4-day estrous cycle and the hearts were collected and frozen immediately. At this time, blood was also collected for determination of $\mathrm{E}_{2}$ and aldosterone levels. All experimental procedures met guidelines of the Institutional Animal Care and Use Committee at Harvard University.

\section{Experimental procedures}

We examined the following groups of rats receiving Purina Lab Chow 5001 (Ralston Purina Co., St Louis, MO, USA) and $1 \% \mathrm{NaCl}$ to drink: 1) OVX rats implanted with pellets containing placebo and minipumps containing saline, $n=7$; 2) OVX rats implanted with $\mathrm{E}_{2}$ pellets, $n=7$; 3) OVX rats implanted with placebo pellets and receiving L-NAME/Ang II treatment, $n=7$; and 4) OVX rats implanted with $\mathrm{E}_{2}$ pellets and receiving L-NAME/Ang II treatment, $n=7$. Pellets containing $\mathrm{E}_{2}$ (\#E121, Innovative Research of America, Sarasota, FL, USA, $0.5 \mathrm{mg} /$ pellet, 21-day release) or placebo (\#C111, Innovative Research of America) were implanted subcutaneously in each rat 7-10 days after ovariectomy. These $\mathrm{E}_{2}$ pellets were designed to achieve plasma estradiol levels in the high-normal physiological range for cycling female rats $(100-150 \mathrm{pg} / \mathrm{ml})$. One week after implantation of the pellets, animals were treated with L-NAME/Ang II as described previously (Oestreicher et al. 2006). Briefly, rats received drinking water containing 1\% NaCl. L-NAME (Sigma, $40 \mathrm{mg} / \mathrm{kg}$ per day) was administered for 14 days via a subcutaneously implanted pellet (Innovative Research of America). Saline or Ang II (Sigma, 0.225 mg/kg per day) was administered via Alzet osmotic minipumps (Model 2001, Durect Corporation, Cupertino, CA, USA; $1 \cdot 0 \mu \mathrm{l} / \mathrm{h}, 7$ days) for the final 3 days. Pellets and minipumps were implanted under general anesthesia using isoflurane. On day 14, death was induced by administration of isoflurane followed by the immediate collection of blood and hearts.

\section{Histological evaluation}

The heart tissue for histological evaluation was processed into paraffin blocks. The heart sections $(5 \mu \mathrm{m})$ were stained with hematoxylin and eosin and examined using light microscopy by a pathologist unaware of the treatment group assignment. The histologic sections of the hearts were scored for myocardial damage on a scale from 0 to 4 as follows: 0 , normal histology; 1, focal interstitial inflammatory infiltrates without myocyte injury; 2, a single focus of interstitial inflammatory infiltrate associated with myocyte injury; 3 , two or three foci of interstitial inflammatory infiltrates associated with myocyte injury; and 4, four or more foci of inflammatory infiltrates associated with myocyte injury.

\section{Measurements and assays}

Daily food intake, water intake, body weight, and urine output were recorded. Systolic blood pressure (SBP) was measured in conscious animals by tail-cuff plethysmography (Blood Pressure Analyzer, Model 179, IITC Life Science, Woodland Hills, CA, USA). Plasma estradiol was measured with the DPC Double Antibody Estradiol (analytical sensitivity of $1.4 \mathrm{pg} / \mathrm{ml}$ ) as described previously (Oestreicher et al. 2006). Aldosterone was measured using the DPC Coat-A-Count Aldosterone RIA as described previously (Turchin et al. 2006; DPC Diagnostic Products, Los Angeles, CA, USA).

\section{Western blot analysis}

The heart tissues were homogenized in $1 \mathrm{ml}$ ice-cold lysing solution (Bio-Rad cell lysis kit - catalog \#171-304012). The ground tissue was transferred to a clean microcentrifuge tube and frozen at $-70{ }^{\circ} \mathrm{C}$. Homogenates were then thawed and sonicated on ice (Fisher Sonic Dismembrator, model 300, Fisher Scientific, Pittburgh, PA, USA). Samples were then centrifuged at $4800 \mathrm{~g}$ for $4 \mathrm{~min}$ at $4{ }^{\circ} \mathrm{C}$. Supernatant was collected without disturbing the pellets. Protein concentration in the supernatant was determined using modified Lowry assay (RC DC protein assay, Bio-Rad catalog \#500-0119, Bio-Rad). Supernatants $(20 \mu \mathrm{g}$ of protein concentration) were combined 
at least 1:2 with sample buffer $(62.5 \mathrm{mM}$ Tris, $\mathrm{pH} 6 \cdot 8,2 \%$ SDS, $25 \%$ glycerol, $0 \cdot 01 \%$ bromophenol blue, $200 \mathrm{mM}$ $\beta$-mercaptoethanol), heated at $95^{\circ} \mathrm{C}$ for $4 \mathrm{~min}$, and size fractionated by electrophoresis on $12.5 \%$ SDS-polyacrylamide gels using $1 \times$ of the following $10 \times$ buffer: $250 \mathrm{mM}$ Tris base, 1.92 M glycine, $34.7 \mathrm{mM}$ SDS. Proteins were electrophoretically transferred to Hybond-ECL nitrocellulose membranes (Amersham Bioscience) using the following transfer buffer: $25 \mathrm{mM}$ Tris, $192 \mathrm{mM}$ glycine, $20 \% \mathrm{v} / \mathrm{v}$ methanol, $\mathrm{pH}$ 8.3. The membranes were blocked in 5\% nonfat dried milk in PBS-T $\left(80 \mathrm{mM} \mathrm{Na} 2 \mathrm{HPO}_{4}\right.$ anhydrous, $20 \mathrm{mM} \mathrm{NaH} \mathrm{PO}_{4}, 100 \mathrm{mM}$ $\mathrm{NaCl}$, and $0 \cdot 1 \%$ Tween 20 ) for $1 \mathrm{~h}$ at room temperature on an orbital shaker. Primary antibody incubation was incubated overnight at $4{ }^{\circ} \mathrm{C}$ with antibody diluent consists of $1 \%$ nonfat dried milk in PBS-T. Equal loading was assessed by reprobing membranes with an antibody to $\beta$-actin (1:20 000; Clone AC15, Sigma). After overnight incubation, the bound antibody was detected by enhanced chemiluminescence (Western Lightning Reagent Plus, Perkin-Elmer Life Sciences, Boston, MA, USA) with HRP-conjugated goat anti-rat IgG (sc-2006, Santa Cruz Biotechnology Inc., Santa Cruz, CA, USA, dilution 1:3000), or goat anti-mouse IgG (sc-2005, Santa Cruz, dilution 1:5000), or goat anti-rabbit IgG (sc-2004, Santa Cruz, dilution 1:5000). Developed $\mathrm{X}$ ray films were scanned and densitometric analysis was performed with the ImageQuant 5.2 software (Molecular Dynamics, Piscataway, NJ, USA). To control for inter-gel variations we used the following procedure. On each 15-well mini-gels, we analyzed three to four samples from each of the four treatment groups; two samples were used for normalization between mini-gels. All western blots were re-probed once with anti- $\beta$-actin antibody and the protein of interest was normalized to $\beta$-actin to correct for loading variability. Samples were re-analyzed on a separate western blot to confirm results. All values were expressed relative to the average of the OVX rats receiving control treatment.

\section{Antibodies}

We used the following antibodies to detect the proteins and receptors of interest by western blot: ESR1 (\#GR17, Calbiochem, San Diego, CA, USA, dilution 1:1000); ESR2 (\#sc-8974, Santa Cruz Biotechnology Inc., dilution 1:500); and $\mathrm{AT}_{1} \mathrm{R}$ (\#sc-1173, Santa Cruz, dilution 1:1000). The specificity of the antibody to $\mathrm{AT}_{1} \mathrm{R}$ was confirmed by receptor binding assays as described previously (Oestreicher et al. 2006); CAV3 (\#RDI-CAVEOL3abrx, Research Diagnostics, Concord, MA, USA, dilution 1:10 000); eNOS (\#N30030/L14, BD Transduction Laboratories, San Jose, CA, USA, dilution 1:2500); PRKCD (\#610397BD Transduction Laboratories, dilution 1:1000); PAI-1 (\#612024, BD Transduction Laboratories, dilution 1:2500); ED-1 (\#554954, BD Transduction Laboratories, dilution 1:1000); phosphorylated protein kinase C (pPRKC; \#9371S, Cell Signaling, Danvers, MA, USA, dilution 1:1000); and pMAPK3/1 (\#9101S, Cell Signaling, dilution 1:2000); peNOS (9571S, Cell Signaling, dilution 1:1000. The peNOS antibody is directed against phosphorylated serine
1177. This site is specific for eNOS activation.); and OPN (\#ab8448, Abcam, Cambridge, MA, USA, dilution 1:5000).

\section{Statistical analysis}

The statistical significance of the differences between the group means for the data were determined by one-way ANOVA followed by Newman-Keuls post hoc test for multiple comparisons. $P \leq 0 \cdot 05$ was considered statistically significant. Values are expressed as mean \pm s.E.M.

\section{Results}

\section{L-NAME, Ang II, and $E_{2}$ effects on cardiac histology}

Treatment with L-NAME and Ang II caused a significant increase in cardiac damage compared with control treatment (Figs 1 and 2). Damaged hearts showed inflammatory infiltrates associated with myocyte injury (Fig. 1C and D). $\mathrm{E}_{2}$ treatment had no significant effect on cardiac histology in the control NaCl-treated OVX rats or in the L-NAME/Ang II-treated OVX rats (Figs 1B, D and 2).

\section{$\mathrm{E}_{2}$ effects in healthy young $\mathrm{OVX}$ rats}

OVX rats receiving $1 \% \mathrm{NaCl}$ in the drinking water were implanted with subcutaneous pellets containing either placebo or $\mathrm{E}_{2}$. After 14 days, $\mathrm{E}_{2}$ levels were significantly higher in the OVX rodents receiving $\mathrm{E}_{2}$ when compared with those not receiving $E_{2}$ (Table 1). Consistent with the known effects of $E_{2}$ in rodents, OVX rats receiving $\mathrm{E}_{2}$ had lower body weights, higher uterine weights, and higher uterine/body weight ratios than OVX rats not receiving $\mathrm{E}_{2}$ (Table 1). SBP and heart weights were similar in the $\mathrm{E}_{2}$ - and placebo-treated OVX rats (Table 1).

Protein levels of ESR1 (Fig. 3A) and ESR2 (Fig. 3B) were increased in the heart tissues of OVX rats receiving $\mathrm{E}_{2}$ treatment when compared with OVX rats not treated with $\mathrm{E}_{2}$ $(1 \cdot 3$-fold increase for ESR $1, P<0 \cdot 05$ and $1 \cdot 6$-fold increase for ESR2, $P<0 \cdot 001)$. Furthermore, $E_{2}$ treatment increased cardiac levels of eNOS $(P<0 \cdot 05)$ and phosphorylated peNOS $(P<0 \cdot 05)$, the active form of eNOS, when compared with estrogen-deficient OVX rats (Fig. 4A and $\mathrm{B})$, a result consistent with the known effects of estrogen. $\mathrm{E}_{2}$ treatment also resulted in higher cardiac levels of CAV3 (1.55fold increase, $P<0 \cdot 01$, Fig. 4C), a caveolae protein that is part of the $\mathrm{E}_{2}$ signaling pathway in cardiomyocytes.

Plasma aldosterone levels were significantly elevated in rats receiving $E_{2}$ when compared with animals that did not receive $\mathrm{E}_{2}$ (Table 1). Furthermore, $\mathrm{E}_{2}$ treatment increased protein levels of $\mathrm{AT}_{1} \mathrm{R}$ in the heart homogenates when compared with OVX rats not receiving $\mathrm{E}_{2}$ (Fig. 5A, $P<0 \cdot 05$ ).

Cardiac levels of PRKCD were increased by $2 \cdot 5$-fold (Fig. 5B, $P<0 \cdot 01$ ), pPRKC by $2 \cdot 2$-fold (Fig. $5 \mathrm{C}, P<0 \cdot 05$ ), and pMAPK3/ 1 by $1 \cdot 3$-fold (Fig. $5 \mathrm{D}, P<0 \cdot 05$ ) in rats implanted with $E_{2}$ pellets versus those implanted with placebo pellets. 

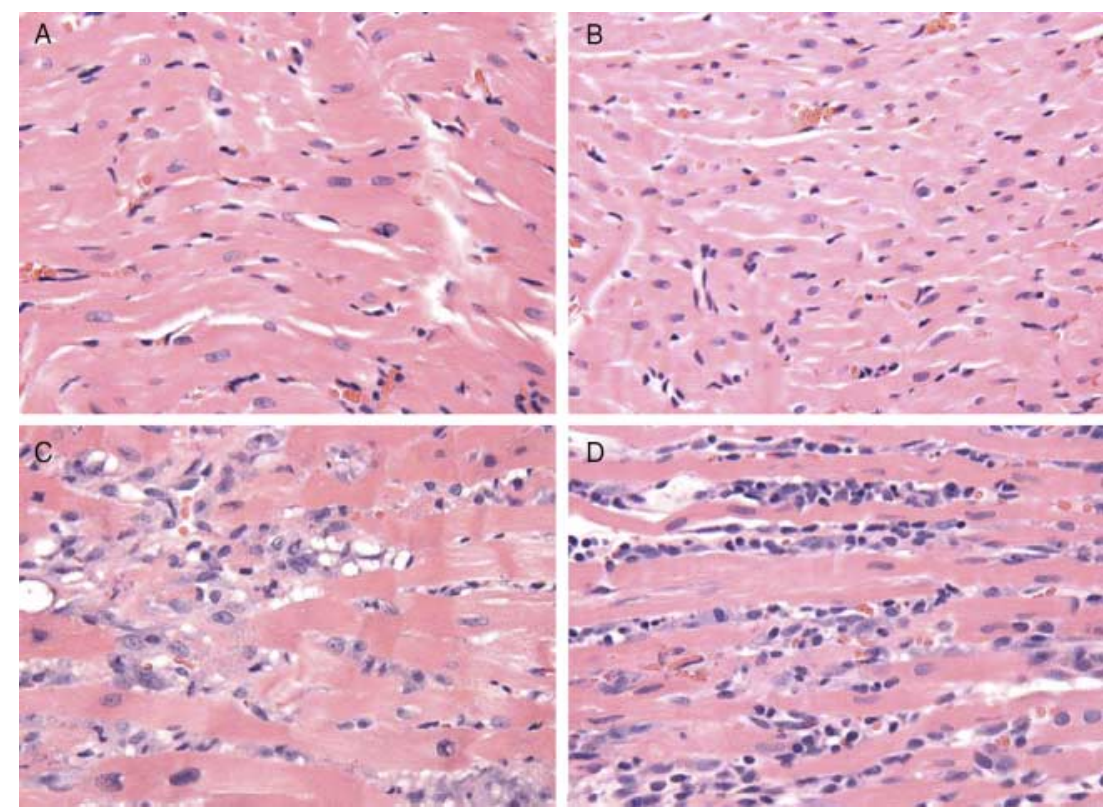

Figure 1 Pathologic assessment of myocardial injury. Shown are representative histological sections of the myocardium stained with hematoxylin and eosin at $400 \times$ magnification. In the OVX rats treated with placebo (A) or estrogen (B), there is essentially normal histology. In the L-NAME/Ang II-treated rats treated either with placebo $(C)$ or estrogen $(\mathrm{D})$ there are inflammatory infiltrates associated with myocyte injury. Full colour version of this figure available via http://dx.doi.org/10.1677/JOE-08-0199.

We determined the effect of $\mathrm{E}_{2}$ on cardiac expression of PAI-1 (an $\mathrm{E}_{2}$-responsive prothrombotic factor (Smith et al. 2004), the chemokine osteopontin (OPN), and ED-1 (a protein expressed by monocytes/macrophages)). The cardiac levels of PAI-1 protein were increased in rats receiving $\mathrm{E}_{2}$ when compared with

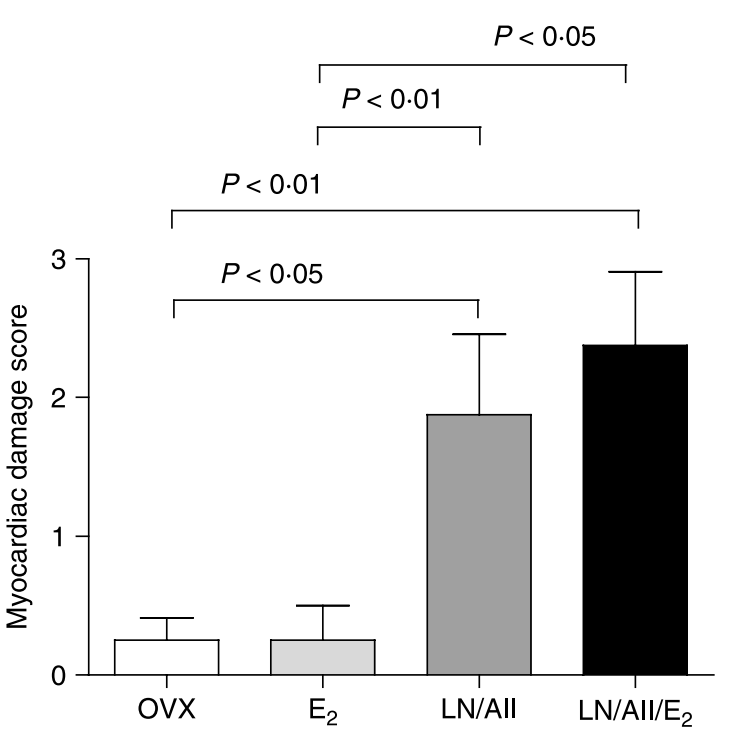

Figure 2 Myocardial damage scores in ovariectomized rats receiving placebo $(\mathrm{OVX})$, estrogen $\left(\mathrm{E}_{2}\right)$, L-NAME/Ang II (LN/AII), and L-NAME/Ang II plus $\mathrm{E}_{2}\left(\mathrm{LN} / \mathrm{AII} / \mathrm{E}_{2}\right)$. those not receiving $\mathrm{E}_{2}$ (Fig. $6 \mathrm{~A}, P<0 \cdot 01$ ). Furthermore, $\mathrm{E}_{2}$ treatment significantly increased cardiac levels of ED-1 (Fig. 6B, $P<0 \cdot 01$ ) and OPN (Fig. 6C, $P<0 \cdot 05$ ). Thus, $\mathrm{E}_{2}$ increases prothrombotic and inflammatory factors in cardiac tissue in OVX female rats that were otherwise healthy.

\section{$E_{2}$ effects in OVX rats receiving L-NAME/Ang II}

OVX rats treated with L-NAME/Ang II plus $E_{2}$ had higher blood levels of $E_{2}$, decreased body weight, increased uterine weight, and increased uterine/body weight ratio compared with OVX rats receiving L-NAME/Ang II (Table 1). $\mathrm{E}_{2}$ treatment did not affect the heart weight or SBP of L-NAME/ Ang II-treated rats. As occurred in rats drinking $1 \% \mathrm{NaCl}, \mathrm{E}_{2}$ treatment increased cardiac levels of ESR 1 and ESR2 in rats receiving L-NAME/Ang II, a treatment that itself did not affect ESR levels (data not shown).

L-NAME/Ang II treatment alone did not alter cardiac levels of eNOS, peNOS, or $\mathrm{AT}_{1} \mathrm{R}$, nor plasma levels of aldosterone. By contrast, $\mathrm{E}_{2}$ treatment increased protein levels of eNOS (Fig. 7A) in the hearts from L-NAME/Ang II-treated rats. The magnitude of this $\mathrm{E}_{2}$ effect in the L-NAME/Ang II/NaCl-treated rats was similar to that observed in OVX rats drinking $1 \% \mathrm{NaCl}$. However, $\mathrm{E}_{2}$ treatment did not increase peNOS levels in rats receiving L-NAME/Ang II (Fig. 7C). As occurred in OVX rats drinking $1 \% \mathrm{NaCl}, \mathrm{E}_{2}$ treatment increased plasma aldosterone and cardiac $\mathrm{AT}_{1} \mathrm{R}$ levels in rats receiving L-NAME/Ang II/NaCl. 
Table 1 Effects of $E_{2}$ treatment on body, uterine and heart weights, blood pressure, and $E_{2}$ and aldosterone levels. All values are mean \pm s.E.M.; $n=7$. The statistical significance of the differences between group means for the data was determined by one-way ANOVA followed by Newman-Keuls post hoc test for multiple comparisons

\begin{tabular}{|c|c|c|c|c|}
\hline & \multicolumn{2}{|l|}{ OVX } & \multicolumn{2}{|c|}{ OVX/L-NAME/Ang II } \\
\hline & Placebo & $\mathrm{E}_{2}$ & Placebo & $\mathrm{E}_{2}$ \\
\hline $\mathrm{E}_{2}(\mathrm{pg} / \mathrm{ml})$ & $11 \cdot 2 \pm 2 \cdot 1$ & $212 \cdot 6 \pm 130 \cdot 8^{*}$ & $10 \cdot 3 \pm 0 \cdot 9$ & $168 \cdot 0 \pm 85 \cdot 7^{\dagger}$ \\
\hline ALDO (ng/dl) & $15 \cdot 3 \pm 4 \cdot 8$ & $39 \cdot 0 \pm 5 \cdot 0^{*}$ & $11 \cdot 51 \pm 5 \cdot 3$ & $33 \cdot 5 \pm 5 \cdot 7^{\dagger}$ \\
\hline $\mathrm{SBP}(\mathrm{mmHg})$ & $111 \cdot 0 \pm 5 \cdot 0$ & $110 \pm 4 \cdot 0$ & $153 \pm 7 \cdot 0^{\ddagger}$ & $158 \pm 5 \cdot 0^{\S}$ \\
\hline $\mathrm{BW}(\mathrm{g})$ & $324 \cdot 0 \pm 6 \cdot 6$ & $255 \pm 11 \cdot 0^{*}$ & $308 \pm 3 \cdot 4$ & $251 \pm 7 \cdot 9^{+}$ \\
\hline HW (g) & $1 \cdot 1 \pm 0 \cdot 1$ & $1 \cdot 14 \pm 0 \cdot 03$ & $1 \cdot 14 \pm 0 \cdot 02$ & $1 \cdot 09 \pm 0 \cdot 04$ \\
\hline UW (g) & $0 \cdot 10 \pm 0 \cdot 01$ & $0 \cdot 70 \pm 0.09 *$ & $0 \cdot 10 \pm 0 \cdot 01$ & $0 \cdot 70 \pm 0.09^{+}$ \\
\hline UW/BW (mg/g) & $0 \cdot 31 \pm 0 \cdot 01$ & $2 \cdot 70 \pm 0 \cdot 3^{*}$ & $0.33 \pm 0.01$ & $2 \cdot 72 \pm 0 \cdot 32^{+}$ \\
\hline
\end{tabular}

$\mathrm{E}_{2}$, estradiol; ALDO, aldosterone; SBP, systolic blood pressure; UW, uterine weight. ${ }^{*} P \leq 0 \cdot 05$ for OVX/placebo versus $\mathrm{OVX} / \mathrm{E}_{2},{ }^{+} P \leq 0 \cdot 05$ for $\mathrm{OVX} / \mathrm{L}-\mathrm{NAME} / \mathrm{Ang}$ II placebo versus OVX/L-NAME/Ang II/E $E_{2} .{ }^{\ddagger} P \leq 0 \cdot 05$ for OVX/placebo versus OVX/L-NAME/Ang II/placebo, ${ }^{\$} P \leq 0 \cdot 05$ for $O V X / E_{2}$ versus $O V X / L-N A M E / A n g ~ I I / E_{2}$.

Both $\mathrm{E}_{2}$ and L-NAME/Ang II treatment increased cardiac levels of PRKCD and PAI-1, and these effects were additive (Fig. 8A and B). Finally, while $\mathrm{E}_{2}$ increased cardiac levels of pPRKC, pMAPK3/1, ED-1, and OPN in L-NAME/Ang II/ $\mathrm{NaCl}$-treated animals as occurred in the rats receiving $1 \%$ $\mathrm{NaCl}$ alone, L-NAME/Ang II treatment did not affect these factors and there was no additive effect of these two treatments (data not shown).

\section{Discussion}

These studies determined the cardiac effects of $\mathrm{E}_{2}$ treatment in OVX female rats. In OVX, but otherwise healthy female rats, $E_{2}$ increased cardiac expression of eNOS and peNOS, which would be expected to enhance NO production and, thus, have a beneficial cardiac effect. However, $E_{2}$ also increased cardiac levels of $\mathrm{AT}_{1} \mathrm{R}$ and other factors (PAI-1, OPN, ED-1, and PRKCD) known to induce inflammation, thrombosis, and/or cardiac damage. In the model of cardiovascular injury induced by Ang II and NOS inhibition, the $E_{2}$-mediated increase in peNOS was lost, while $E_{2^{-}}$ mediated increases in cardiac $\mathrm{AT}_{1} \mathrm{R}, \mathrm{PAI}-1, \mathrm{OPN}, \mathrm{ED}-1$, and PRKCD were maintained. Furthermore, $\mathrm{E}_{2}$ acted additively with L-NAME/Ang II treatment to increase cardiac levels of PAI-1 and PRKCD. Thus, these data demonstrate that $\mathrm{E}_{2}$ increases the expression of cardiac proteins that have beneficial cardiac effects (peNOS) as well as those that have detrimental cardiac effects (e.g. $\mathrm{AT}_{1} \mathrm{R}$ and PAI-1). When the beneficial effects of $E_{2}$ on peNOS were blocked with a NOS inhibitor, the detrimental effects of $\mathrm{E}_{2}$ dominated.

Our results are consistent with the well-known beneficial effect of $E_{2}$ to increase peNOS leading to increased NO and improved vasodilation (Reis et al. 1994, Collins et al. 1995). We also demonstrated an increase in pMAPK3/1 with $E_{2}$ treatment. This latter result is consistent with studies demonstrating the activation of the MAPK3/1 pathway by estrogen in multiple cell types and tissues, including endothelial cells (Gorodeski et al. 1995), neuronal cells (Alexaki et al. 2006), smooth muscle cells (Keyes et al.
1996), and myocardium (Patten et al. 2004, Pedram et al. 2005). These non-genomic effects of estrogen are mediated via its two receptors, ESR 1 and ESR2 (Mendelsohn \& Karas 1999). We demonstrated that $E_{2}$ increased expression of both ESR 1 and ESR2 in the heart tissues, consistent with other reports showing that $\mathrm{E}_{2}$ replacement increases expression of ESR1, and ESR2 in the heart tissues from aged rats (Xu et al. 2003). In our study, the increase of ESR 2 was greater than that of ESR 1, possibly due to differential effects of estradiol on synthesis and/or degradation of ESR subtypes (Barchiesi et al. 2004). ESRs interact with the caveolae anchoring protein CAV3 to mediate the rapid, non-genomic effects of estrogen and other steroids, and increasing CAV3 levels tends to inhibit eNOS activation (Hisamoto \& Bender 2005). Estrogen treatment increased CAV3 in our studies, raising the possibility that estrogen-mediated changes in caveolin levels modulate the effects of estrogens and other steroids on intracellular signaling pathways (Feron \& Kelly 2001, Damy et al. 2004, Williams \& Lisanti 2004).

The observation that $\mathrm{E}_{2}$ increases protein levels of $\mathrm{AT}_{1} \mathrm{R}$ in the hearts of healthy, OVX rats and L-NAME/Ang II-treated rats is consistent with the reports that $E_{2}$ increases $A T_{1} R$ expression in the uteri of healthy rats (Krishnamurthi et al. 1999) and in the renal cortex of rats receiving L-NAME/Ang II (Oestreicher et al. 2006). In the latter study, the level of $\mathrm{AT}_{1} \mathrm{R}$ expression correlated with proteinuria (Oestreicher et al. 2006). Similarly, estrogen has been shown to increase cardiac and renal injury in other animal models characterized by an activated RAAS. In the stroke prone spontaneously hypertensive rat, ovariectomy reduced stroke and renal injury, while estrogen replacement increased this injury (Stier et al. 2003). The hypertensive mRen2.Lewis rat is a transgenic rat strain carrying the mouse ren-2 renin gene backcrossed into the inbred Lewis rat. In the hypertensive mRen2.Lewis female rat, ovariectomy reduced proteinuria, renal injury, and blood levels of the inflammatory marker C-reactive protein in older, 64-week-old mRen2.Lewis rats on a high-salt diet (Yamaleyeva et al. 2007). Our observation that $E_{2}$ and L-NAME/Ang II treatment have additive effects on cardiac PAI-1 is consistent with these studies, and together these 
A ESR1 $\sin$

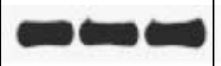

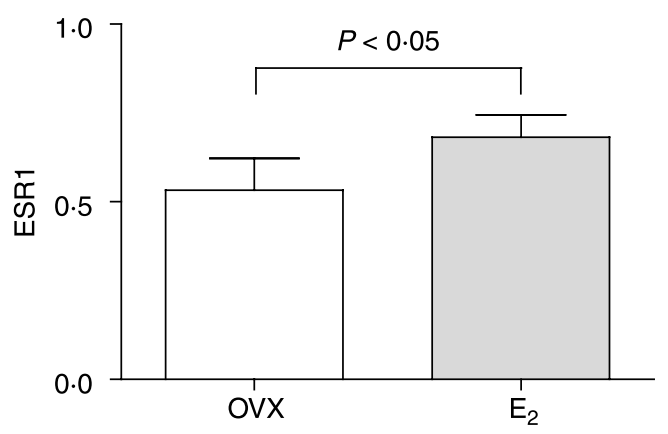

B ESR2

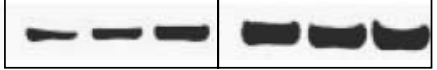

$54 \mathrm{kDa}$

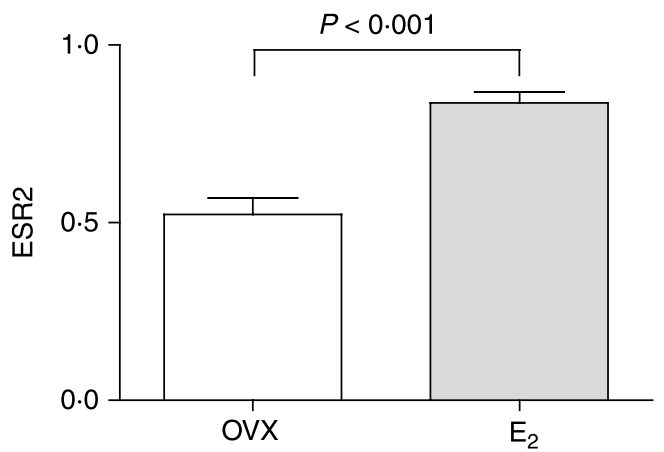

Figure $3 \mathrm{E}_{2}$ treatment increases ESR1 and ESR2 protein expression in the heart tissue of OVX rats. Western blot of heart tissue showing results for three representative animals $(20 \mu \mathrm{g}$ of total protein per lane, each lane represent an individual animal) from OVX rats receiving placebo $(\mathrm{OVX})$ and $\mathrm{OVX} \mathrm{E}_{2}$-treated rats $\left(\mathrm{E}_{2}\right)$. (A) $66 \mathrm{kDa}$ band for ESR1 and (B) $54 \mathrm{kDa}$ band for ESR2.

animal studies demonstrate that $\mathrm{E}_{2}$ promotes Ang II-mediated cardiovascular injury. $\mathrm{AT}_{1} \mathrm{R}$ is expressed in endothelial cells, vascular smooth muscle cells, and cardiomyocytes (Bueno et al. 2000). Additional studies are needed to determine which cell types within the heart demonstrate altered $\mathrm{AT}_{1} \mathrm{R}$ expression with estrogen treatment. Our observation that $\mathrm{E}_{2}$ increases $\mathrm{AT}_{1} \mathrm{R}$ protein provides a potential mechanism for the increase in intrarenal Ang II activity leading to a reduction in renal blood flow in postmenopausal women treated with estrogen (Seely et al. 2004).

In contrast to our observations, estrogen replacement was reported to decrease cardiac $\mathrm{AT}_{1} \mathrm{R}$, increase cardiac Ang II type 2 receptor, and improve heart remodeling in 1-year-old OVX rats (Xu et al. 2003). Estrogen also decreased $\mathrm{AT}_{1} \mathrm{R}$ levels in the adrenal and pituitary glands of OVX rats
A
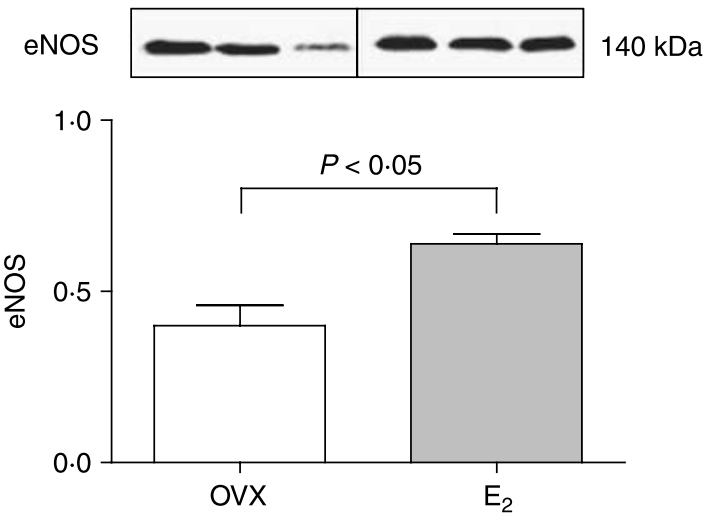

B
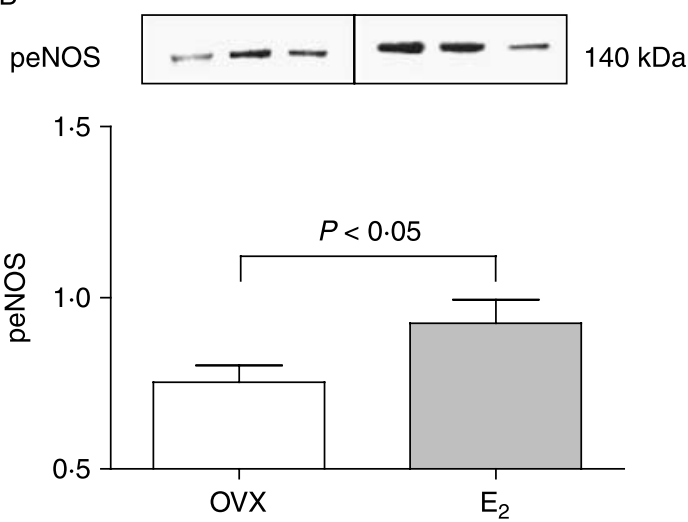

C
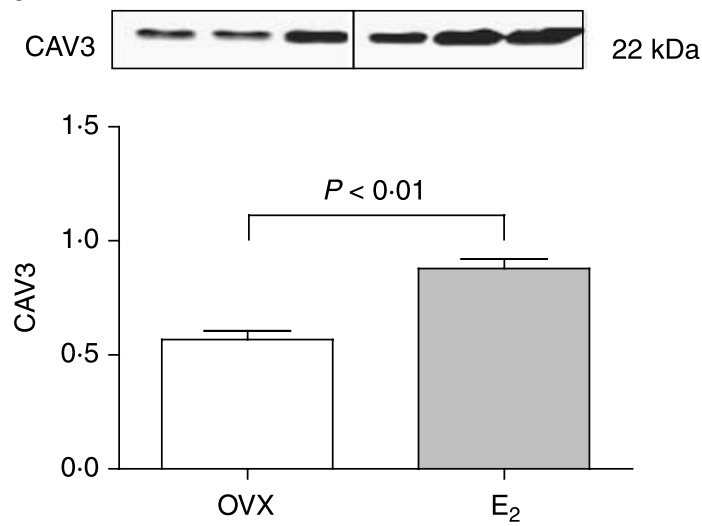

Figure $4 E_{2}$ treatment increases eNOS, peNOS, and CAV3 protein expression in the heart tissue of OVX rats. Western blot of heart tissue showing results for three representative animals ( $20 \mu \mathrm{g}$ of total protein per lane, each lane represent an individual animal) from OVX rats receiving placebo $(\mathrm{OVX})$ and $\mathrm{OVX} \mathrm{E}_{2}$-treated rats $\left(\mathrm{E}_{2}\right)$. (A) $140 \mathrm{kDa}$ band for eNOS, (B) $140 \mathrm{kDa}$ band for peNOS, and (C) $22 \mathrm{kDa}$ band for CAV3. 


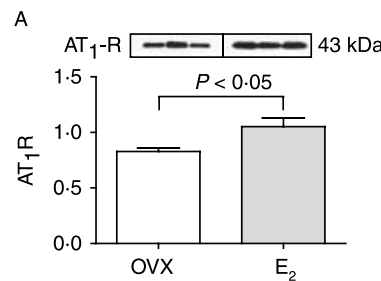

$B$

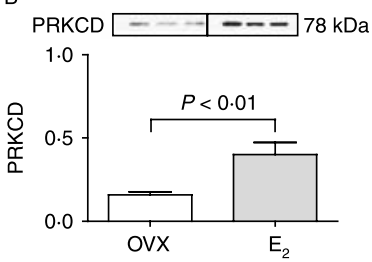

C

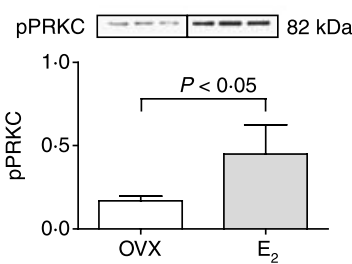

D
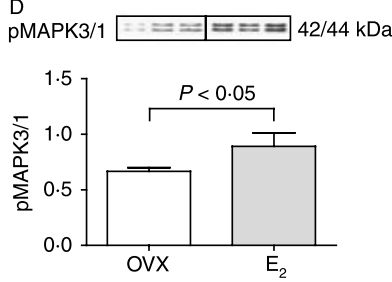

Figure 5 Effect of estrogen on $\mathrm{AT}_{1} \mathrm{R}$ and intracellular signaling pathways. Western blot of heart tissue showing results for three representative animals $(20 \mu \mathrm{g}$ of total protein per lane, each lane represent an individual animal) from OVX rats receiving placebo $(\mathrm{OVX})$ and $\mathrm{OVX} \mathrm{E}_{2}$-treated rats $\left(\mathrm{E}_{2}\right)$. (A) $43 \mathrm{kDa}$ band for $A \mathrm{~T}_{1} \mathrm{R},(\mathrm{B})$ $78 \mathrm{kDa}$ band for PRKCD, (C) $82 \mathrm{kDa}$ band for pPRKC, and (D) 42/44 kDa band for pMAPK3/1.

(Wu et al. 2003). It is likely that the effects of estrogen on $\mathrm{AT}_{1} \mathrm{R}$ expression and Ang II-mediated injury differ depending on the experimental animal model. Factors such as age, genotype, dietary sodium intake, and underlying activity of the RAAS or NO system may modify the effects of estrogen. In our study, L-NAME treatment blocked the beneficial effects of $\mathrm{E}_{2}$ on peNOS levels. Additionally, as $\mathrm{E}_{2}$ increased cardiac levels of the Ang II receptor $\mathrm{AT}_{1} \mathrm{R}$, the co-administration of Ang II in our rat model further amplified the adverse cardiac effects of $E_{2}$ treatment.

In the present study, $\mathrm{E}_{2}$ treatment increased plasma aldosterone levels in OVX rats receiving either placebo or L-NAME/Ang II. It is unlikely that $\mathrm{E}_{2}$ increased systemic aldosterone levels through increases in adrenal $A T_{1} R$ as other investigators have shown that $\mathrm{E}_{2}$ decreases $\mathrm{AT}_{1} \mathrm{R}$ levels in adrenal tissue (Wu et al. 2003). However, this increase may result from $\mathrm{E}_{2}$-mediated increases in angiotensinogen leading to increases in Ang II, and thus increased adrenal aldosterone production (Klett et al. 1992, Gallagher et al. 1999).

It is now well established that aldosterone causes cardiovascular injury with activation of the mineralocorticoid receptor causing increases in PAI-1, vascular injury, and inflammation, as well as myocardial necrosis, inflammation, and fibrosis (Rocha et al. 2000, 2002, Oestreicher et al. 2003). Blockade of the mineralocorticoid receptor markedly reduces cardiovascular injury caused by L-NAME/Ang II treatment (Rocha et al. 2000, Oestreicher et al. 2003). Given the effects of $\mathrm{E}_{2}$ on $\mathrm{AT}_{1} \mathrm{R}$ and aldosterone, it would be of interest to determine whether mineralocorticoid receptor blockade prevents the adverse cardiovascular effects of $\mathrm{E}_{2}$.

There are some limitations to these studies. Consistent with previous studies (Rocha et al. 2000), we did not detect a significant effect of Ang II on aldosterone levels in animals
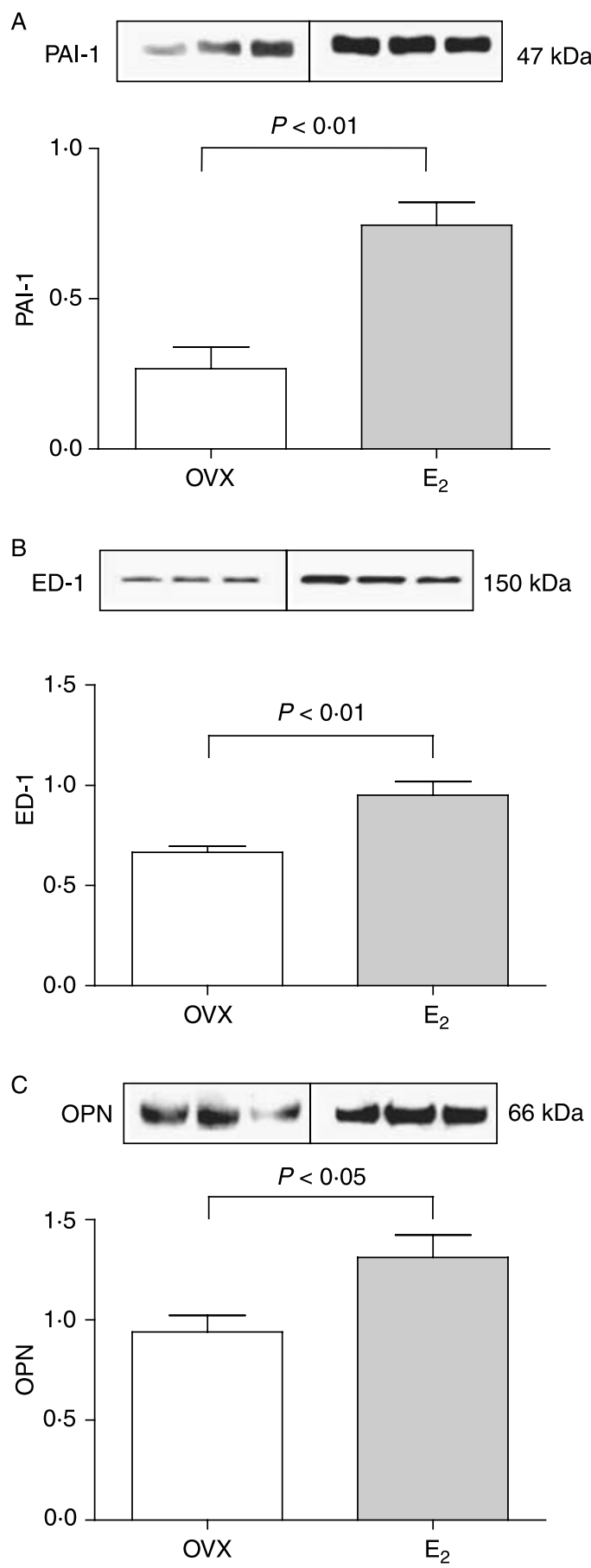

Figure $6 E_{2}$ effect on fibrinolytic and inflammatory proteins in the heart. Western blot of heart tissue showing results for three representative animals ( $20 \mu \mathrm{g}$ of total protein per lane, each lane represent an individual animal) from OVX rats receiving placebo (OVX) and OVX $E_{2}$-treated rats $\left(E_{2}\right)$. (A) $47 \mathrm{kDa}$ band for PAI-1, (B) $150 \mathrm{kDa}$ band for ED-1, and (C) $66 \mathrm{kDa}$ band for OPN. 


\section{A}

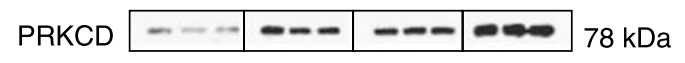

A eNOS $---1---1---140 \mathrm{kDa}$

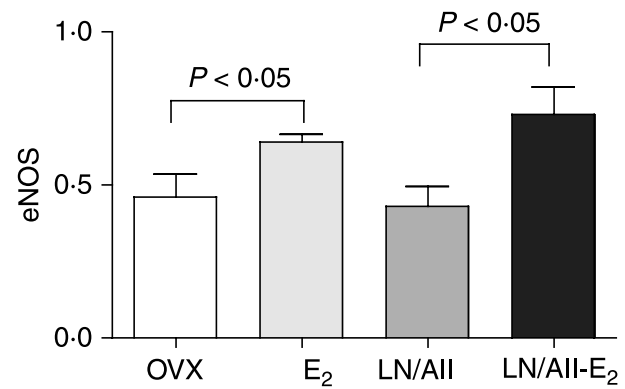

B
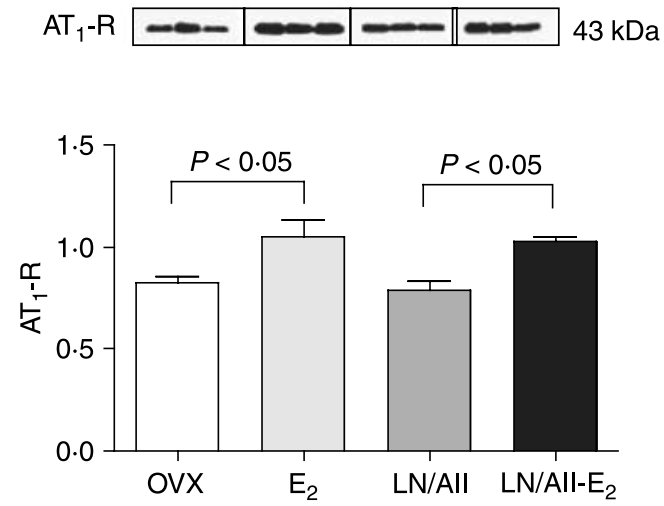

C

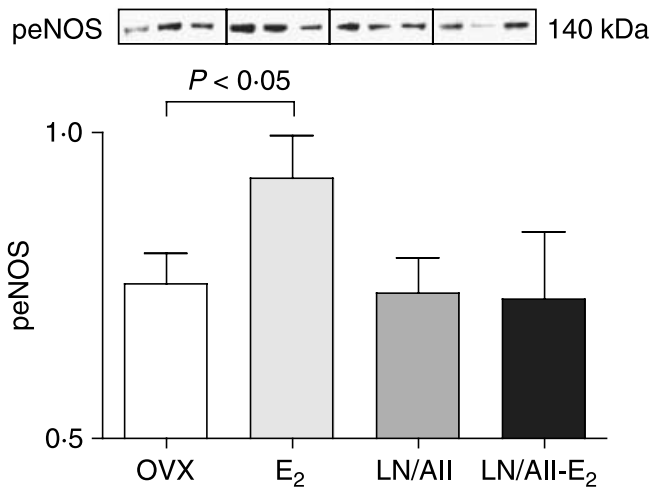

Figure 7 Effect of $E_{2}$ on eNOS, peNOS, and $A T_{1} R$ expression in the hearts of OVX animals treated with L-NAME/Ang II when compared with $E_{2}$ effects in absence of L-NAME/Ang II. Western blot of heart tissue showing results for three representative animals ( $20 \mu \mathrm{g}$ of total protein per lane, each lane represent an individual animal) from OVX rats receiving placebo $(\mathrm{OVX}), \mathrm{OVX} \mathrm{E}_{2}$-treated rats $\left(\mathrm{E}_{2}\right)$, L-NAME/Ang II and placebo (LN/AII), and L-NAME/Ang II and $E_{2}$ treatments $\left(\mathrm{LN} / \mathrm{All} / \mathrm{E}_{2}\right)$. (A) $140 \mathrm{kDa}$ band for eNOS, (B) $43 \mathrm{kDa}$ band for $A T_{1} R$, and $(C) 140 \mathrm{kDa}$ band for peNOS. For ease of comparison, OVX and $E_{2}$ data from Figs $4 \mathrm{~A}, \mathrm{~B}$ and $5 \mathrm{~A}$ are reproduced in this figure.

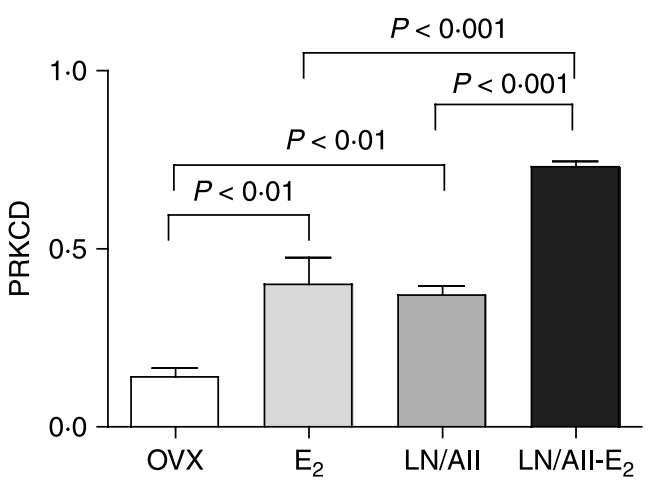

B
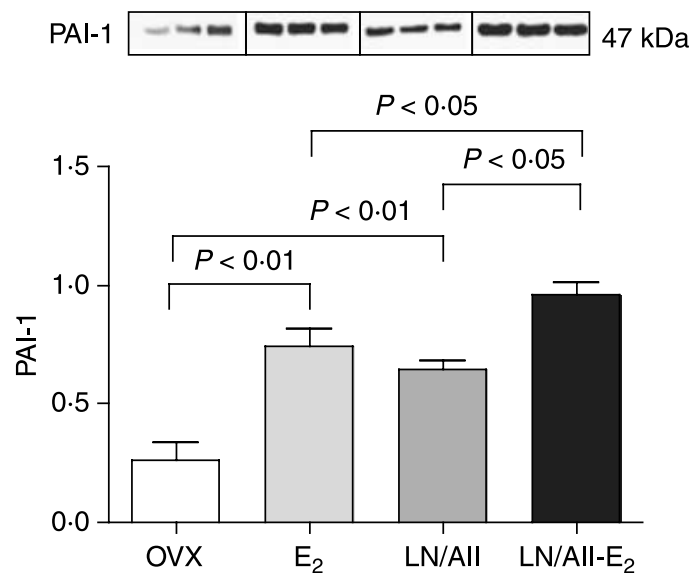

Figure 8 Effect of $E_{2}$ on PRKCD and PAI-1 expression in the hearts of OVX animals treated with L-NAME/Ang II when compared with $E_{2}$ effects in absence of L-NAME/ Ang II. Western blot of heart tissue showing results for three representative animals $(20 \mu \mathrm{g}$ of total protein per lane, each lane represent an individual animal) from OVX rats receiving placebo $(\mathrm{OVX}), \mathrm{OVX} \mathrm{E}_{2}$-treated rats $\left(\mathrm{E}_{2}\right)$, L-NAME/Ang II and placebo (LN/AII), and L-NAME/Ang II and $E_{2}$ treatments (LN/All/ $\mathrm{E}_{2}$ ). (A) $78 \mathrm{kDa}$ band for PRKCD and (B) $66 \mathrm{kDa}$ band for PAI-1. For ease of comparison, OVX and $E_{2}$ data from Figs $5 \mathrm{~B}$ and $6 \mathrm{~A}$ are reproduced in this figure.

receiving L-NAME and a high-salt diet. This is likely due in part to our using a low dose of Ang II that is a subpressor dose in the absence of L-NAME treatment. However, this Ang II dose suppresses plasma renin activity (Rocha et al. 2000) and it is possible that increases in aldosterone production would be detected using a more sensitive method such as 24-h urinary aldosterone levels. Our studies used $0.5 \mathrm{mg}, 21$-day $\mathrm{E}_{2}$ pellets that are commonly used to assess effects of $E_{2}$ and are designed to raise $\mathrm{E}_{2}$ levels into the range observed in pro-estrus (50$150 \mathrm{pg} / \mathrm{ml}$; Klett et al. 1992). This experimental design did not allow us to determine whether there are different $\mathrm{E}_{2}$ dose response characteristics for the beneficial and detrimental 
cardiac effects of $E_{2}$. The wide range of $E_{2}$ values in the $\mathrm{E}_{2}$-treated rats may have introduced variability and the presence of low $\mathrm{E}_{2}$ levels of $\sim 10-12 \mathrm{pg} / \mathrm{ml}$ in the OVX rats may have limited our ability to detect $\mathrm{E}_{2}$ effects. These levels are consistent with the published reports of $\mathrm{E}_{2}(11.3 \pm 3.6 \mathrm{pg} /$ $\mathrm{ml}$ ) in OVX rats and are likely attributable to non-ovarian sources of $\mathrm{E}_{2}$ (Hugel et al. 1999). In addition, our experimental approach did not allow us to determine whether the cardiac effects of $E_{2}$ are due to direct effects of $E_{2}$ or are mediated through other factors. For example, $\mathrm{E}_{2}$ treatment increased the cardiac $\mathrm{AT}_{1} \mathrm{R}$ levels and the activation of either ESRs or $\mathrm{AT}_{1} \mathrm{R}$ can increase PRKC pathways and PAI-1 (Smith et al. 2004, Alexaki et al. 2006). In our study, we used cardiac PAI-1 levels as a marker of early cardiovascular injury as described previously (Oestreicher et al. 2003). While $\mathrm{E}_{2}$ treatment increased PAI-1 and other mediators of cardiovascular injury, the increase in these factors were not associated with a detectable increase in cardiac injury histopathology, possibly due to relative insensitivity of this method and to the relatively short duration of treatment.

These findings indicate that $\mathrm{E}_{2}$ has diverse effects on the heart, some of which are beneficial (increases in eNOS and peNOS), and others of which are detrimental (increases in $\mathrm{AT}_{1} \mathrm{R}$, PAI-1, and cardiac inflammation). The relative balance of these effects may determine whether the overall effect of $E_{2}$ is beneficial or detrimental. Further elucidations of the factors that modify this balance are needed. The finding that $\mathrm{E}_{2}$ increases cardiac expression of $\mathrm{AT}_{1} \mathrm{R}$ has relevance to the mechanisms underlying the adverse cardiac effects of estrogen therapy in postmenopausal women.

\section{Declaration of interest}

The authors declare that there is no conflict of interest that could be perceived as prejudicing the impartiality of the research reported.

\section{Funding}

This work was supported by NIH training grants 5T32HL007609 and DK07529, and NIH research grants HL-63423, HL-069208, HL-67332K24, RR018613, R01 HL67332, and HL-07718.

\section{References}

Alexaki VI, Charalampopoulos I, Kampa M, Nifli AP, Hatzoglou A, Gravanis A \& Castanas E 2006 Activation of membrane estrogen receptors induce pro-survival kinases. Journal of Steroid Biochemistry and Molecular Biology $\mathbf{9 8}$ 97-110.

Barchiesi F, Jackson EK, Imthurn B, Fingerle J, Gillespie DG \& Dubey RK 2004 Differential regulation of estrogen receptor subtypes alpha and beta in human aortic smooth muscle cells by oligonucleotides and estradiol. Journal of Clinical Endocrinology and Metabolism 89 2373-2381.

Brunner F, Maier R, Andrew P, Wolkart G, Zechner R \& Mayer B 2003 Attenuation of myocardial ischemia/reperfusion injury in mice with myocyte-specific overexpression of endothelial nitric oxide synthase. Cardiovascular Research $\mathbf{5 7}$ 55-62.
Bueno OF, De Windt LJ, Tymitz KM, Witt SA, Kimball TR, Klevitsky R, Hewett TE, Jones SP, Lefer DJ, Peng CF et al. 2000 The MEK1-ERK1/2 signaling pathway promotes compensated cardiac hypertrophy in transgenic mice. EMBO Journal $196341-6350$.

Collins P, Rosano GM, Sarrel PM, Ulrich L, Adamopoulos S, Beale CM, McNeill JG \& Poole-Wilson PA 1995 17 $\beta$-Estradiol attenuates acetylcholine-induced coronary arterial constriction in women but not men with coronary heart disease. Circulation 92 24-30.

Crews JK \& Khalil RA 1999 Gender-specific inhibition of $\mathrm{Ca}^{2+}$ entry mechanisms of arterial vasoconstriction by sex hormones. Clinical and Experimental Pharmacology and Physiology 26 707-715.

Damy T, Ratajczak P, Shah AM, Camors E, Marty I, Hasenfuss G, Marotte F, Samuel JL \& Heymes C 2004 Increased neuronal nitric oxide synthasederived NO production in the failing human heart. Lancet 363 1365-1367.

Feron O \& Kelly RA 2001 The caveolar paradox: suppressing, inducing, and terminating eNOS signaling. Circulation Research 88 129-131.

Gallagher PE, Li P, Lenhart JR, Chappell MC \& Brosnihan KB 1999 Estrogen regulation of angiotensin-converting enzyme mRNA. Hypertension 33 323-328.

Gorodeski GI, Yang T, Levy MN, Goldfarb J \& Utian WH 1995 Effects of estrogen in vivo on coronary vascular resistance in perfused rabbit hearts. American Journal of Physiology 269 R1333-R1338.

Hayashi T, Fukuto JM, Ignarro LJ \& Chaudhuri G 1992 Basal release of nitric oxide from aortic rings is greater in female rabbits than in male rabbits: implications for atherosclerosis. PNAS 89 11259-11263.

Herrington DM, Reboussin DM, Brosnihan KB, Sharp PC, Shumaker SA, Snyder TE, Hugel S, Reincke M, Stromer H, Winning J et al. 1999 Evidence against a role of physiological concentrations of estrogen in postmyocardial infarction remodeling. Journal of the American College of Cardiology 34 1427-1434.

Herrington DM, Reboussin DM, Brosnihan KB, Sharp PC, Shumaker SA, Snyder TE, Furberg CD, Kowalchuk GJ, Stuckey TD, Rogers WJ et al. 2000 Effects of estrogen replacement on the progression of coronary-artery atherosclerosis. New England Journal of Medicine 343 522-529.

Hisamoto K \& Bender JR 2005 Vascular cell signaling by membrane estrogen receptors. Steroids 70 382-387.

Huang A, Sun D, Koller A \& Kaley G 2000 17 $\beta$-Estradiol restores endothelial nitric oxide release to shear stress in arterioles of male hypertensive rats. Circulation 101 94-100.

Hügel S, Reincke M, Strömmer H, Winning J, Horn M, Dienesch C, Mora P, Schmidt HH, Allolio B \& Neubauer S 1999 Evidence against a role of physiological concentrations of estrogen in post-myocardial infarction remodelling. Journal of the American College of Cardiologists 34 1427-1434.

Hulley S, Grady D, Bush T, Furberg C, Herrington D, Riggs B \& Vittinghoff E 1998 Randomized trial of estrogen plus progestin for secondary prevention of coronary heart disease in postmenopausal women. Heart and Estrogen/progestin Replacement Study (HERS) Research Group. Journal of the American Medical Association 280 605-613.

Keyes LE, Moore LG, Walchak SJ \& Dempsey EC 1996 Pregnancy-stimulated growth of vascular smooth muscle cells: importance of protein kinase C-dependent synergy between estrogen and platelet-derived growth factor. Journal of Cellular Physiology 166 22-32.

Khalil RA 2005 Sex harmones as potential modulators of vascular action in hypertension. Hypertension 46 249-254.

Klett C, Ganten D, Hellmann W, Kaling M, Ryffel GU, Weimar-Ehl T \& Hackenthal E 1992 Regulation of hepatic angiotensinogen synthesis and secretion by steroid hormones. Endocrinology 130 3660-3668.

Koh KK 2002 Effects of estrogen on the vascular wall: vasomotor function and inflammation. Cardiovascular Research 55 714-726.

Krishnamurthi K, Verbalis JG, Zheng W, Wu Z, Clerch LB \& Sandberg K 1999 Estrogen regulates angiotensin AT1 receptor expression via cytosolic proteins that bind to the $5^{\prime}$ leader sequence of the receptor mRNA. Endocrinology 140 5435-5438.

Manson JE, Hsia J, Johnson KC, Rossouw JE, Assaf AR, Lasser NL, Trevisan M, Black HR, Heckbert SR, Detrano R et al. 2003 Estrogen plus progestin and the risk of coronary heart disease. New England Journal of Medicine 349 $523-534$. 
Martinez DV, Rocha R, Matsumura M, Oestreicher E, Ochoa-Maya M, Roubsanthisuk W, Williams GH \& Adler GK 2002 Cardiac damage prevention by eplerenone: comparison with low sodium diet or potassium loading. Hypertension 39 614-618.

Mendelsohn ME \& Karas RH 1999 The protective effects of estrogen on the cardiovascular system. New England Journal of Medicine 340 1801-1811.

Oestreicher EM, Martinez-Vasquez D, Stone JR, Jonasson L, Roubsanthisuk W, Mukasa K \& Adler GK 2003 Aldosterone and not plasminogen activator inhibitor-1 is a critical mediator of early angiotensin II/NG-nitro-L-arginine methyl ester-induced myocardial injury. Circulation 108 2517-2523.

Oestreicher EM, Guo C, Seely EW, Kikuchi T, Martinez-Vasquez D, Jonasson L, Yao T, Burr D, Mayoral S, Roubsanthisuk W et al. 2006 Estradiol increases proteinuria and angiotensin II type 1 receptor in kidneys of rats receiving L-NAME and angiotensin II. Kidney International 70 1759-1768.

Patten RD, Pourati I, Aronovitz MJ, Baur J, Celestin F, Chen X, Michael A, Haq S, Nuedling S, Grohe C et al. 2004 17 $\beta$-Estradiol reduces cardiomyocyte apoptosis in vivo and in vitro via activation of phosphoinositide-3 kinase/Akt signaling. Circulation Research 95 692-699.

Pedram A, Razandi M, Aitkenhead M \& Levin ER 2005 Estrogen inhibits cardiomyocyte hypertrophy in vitro. Antagonism of calcineurin-related hypertrophy through induction of MCIP1. Journal of Biological Chemistry 280 26339-26348.

Pinto S, Virdis A, Ghiadoni L, Bernini G, Lombardo M, Petraglia F, Genazzani AR, Taddei S \& Salvetti A 1997 Endogenous estrogen and acetylcholine-induced vasodilation in normotensive women. Hypertension $29268-273$.

Reis SE, Gloth ST, Blumenthal RS, Resar JR, Zacur HA, Gerstenblith G \& Brinker JA 1994 Ethinyl estradiol acutely attenuates abnormal coronary vasomotor responses to acetylcholine in postmenopausal women. Circulation 89 52-60.

Rocha R, Stier CT Jr, Kifor I, Ochoa-Maya MR, Rennke HG, Williams GH \& Adler GK 2000 Aldosterone: a mediator of myocardial necrosis and renal arteriopathy. Endocrinology 141 3871-3878.

Rocha R, Martin-Berger CL, Yang P, Scherrer R, Delyani J \& McMahon E 2002 Selective aldosterone blockade prevents angiotensin II/salt-induced vascular inflammation in the rat heart. Endocrinology 143 4828-4836.

Rossouw JE, Anderson GL, Prentice RL, LaCroix AZ, Kooperberg C, Stefanick ML, Jackson RD, Beresford SA, Howard BV, Johnson KC et al. 2002 Risks and benefits of estrogen plus progestin in healthy postmenopausal women: principal results from the Women's Health Initiative randomized controlled trial. Journal of the American Medical Association 288 321-333.
Schunkert H, Danser AH, Hense HW, Derkx FH, Kurzinger S \& Riegger GA 1997 Effects of estrogen replacement therapy on the renin-angiotensin system in postmenopausal women. Circulation 95 39-45.

Seely EW, Brosnihan KB, Jeunemaitre X, Okamura K, Williams GH, Hollenberg NK \& Herrington DM 2004 Effects of conjugated oestrogen and droloxifene on the renin-angiotensin system, blood pressure and renal blood flow in postmenopausal women. Clinical Endocrinology 60 315-321.

Smith LH, Coats SR, Qin H, Petrie MS, Covington JW, Su M, Eren M \& Vaughan DE 2004 Differential and opposing regulation of PAI-1 promoter activity by estrogen receptor alpha and estrogen receptor beta in endothelial cells. Circulation Research 95 269-275.

Stampfer MJ, Colditz GA, Willett WC, Manson JE, Rosner B, Speizer FE \& Hennekens CH 1991 Postmenopausal estrogen therapy and cardiovascular disease. Ten-year follow-up from the nurses' health study. New England Journal of Medicine 325 756-762.

Stier CT Jr, Chander PN, Rosenfeld L \& Powers CA 2003 Estrogen promotes microvascular pathology in female stroke-prone spontaneously hypertensive rats. American Journal of Physiology. Endocrinology and Metabolism 285 E232-E239.

Turchin A, Guo CZ, Adler GK, Ricchiuti V, Kohane IS \& Williams GH 2006 Effect of acute aldosterone administration on gene expression profile in the heart. Endocrinology 147 3183-3189.

Williams TM \& Lisanti MP 2004 The Caveolin genes: from cell biology to medicine. Annals of Medicine 36 584-595.

Wu Z, Zheng W \& Sandberg K 2003 Estrogen regulates adrenal angiotensin type 1 receptors by modulating adrenal angiotensin levels. Endocrinology $\mathbf{1 4 4}$ 1350-1356.

Xu Y, Arenas IA, Armstrong SJ \& Davidge ST 2003 Estrogen modulation of left ventricular remodeling in the aged heart. Cardiovascular Research $\mathbf{5 7}$ 388-394.

Yamaleyeva LM, Pendergrass KD, Pirro NT, Gallagher PE, Groban L \& Chappell MC 2007 Ovariectomy is protective against renal injury in the high-salt-fed older mRen2.Lewis rat. American Journal of Physiology. Heart and Circulatory Physiology 293 H2064-H2071.

\section{Received in final form 10 September 2008 Accepted 16 September 2008 Made available online as an Accepted Preprint 17 October 2008}

